\title{
Correction to: In the Eyes of Uman Pilgrims: A Vision of Place and Its Inhabitants
}

\author{
Alla Marchenko ${ }^{1}$ \\ Published online: 18 May 2019 \\ (c) Springer Nature B.V. 2019
}

\section{Correction to: Cont Jewry (2018) 38:227-247 \\ https://doi.org/10.1007/s12397-017-9247-0}

In the original article, the reference (surname, year) and citation were incorrectly published. The correct reference and citation text are given in this correction.

\section{Surname and year.}

The text I cited appeared in 2013, not in 2009.

Correct surname is Shuman, not Schuman (page 3, in a sentence below).

Three notable exceptions are the works of Akao Mitsuharu, who paid attention to the history of the rebbe's gravesite in Uman and to political tensions there (Mitsuharu 2003, 2007), an ethnographic analysis of structure of the place of pilgrimage by Sam Shuman (Shuman 2013), and my own research paper on the structure of the pilgrimage as a cultural performance (Marchenko 2014).

\section{Surname, year and type of the work cited.}

This is an unpublished undergraduate thesis, not a dissertation. Correct and full reference is given below (page 21 in References).

\section{Reference}

Shuman, Samuel. 2013. Simulacra and S(t)imulation. An Uman Rosh Hashanah Pilgrimage Play/Unpublished Undergraduate Thesis, Columbia University.

The original article can be found online at https://doi.org/10.1007/s12397-017-9247-0.

Alla Marchenko

alla.marchenko82@gmail.com

1 Institute of Philosophy and Sociology, Polish Academy of Sciences, GSSR, room 261, Nowy

Świat 72, 00-330 Warsaw, Poland 
Publisher's Note Springer Nature remains neutral with regard to jurisdictional claims in published maps and institutional affiliations. 